\title{
HIGH MOBILITY GROUP PROTEINS IN YEAST
}

\author{
by \\ JENS G. LITSKE PETERSEN and WILLIAM F. SHERIDAN ${ }^{1}$ \\ Department of Physiology, Carlsberg Laboratory \\ Gamle Carlsberg Vej 10, DK-2500 Copenhagen Valby \\ ${ }^{1}$ Permanent address: Biology Department, University of North Dakota, \\ Grand Forks, N.D. 58202, U.S.A.
}

Keywords: Saccharomyces cerevisiae, nuclei, non-histone proteins, HMG proteins, histones

\begin{abstract}
A class of low molecular weight proteins was extracted from isolated yeast nuclei by $5 \%(\mathrm{w} / \mathrm{v})$ perchloric acid followed by fractional acetone precipitation. Their solubility properties, electrophoretic mobility and the amino acid composition were similar to those of the high mobility group (HMG) chromosomal proteins of higher eukaryotes.
\end{abstract}

\section{INTRODUCTION}

Chromatin contains a group of non-histone proteins designated "the high mobility group" or HMG proteins (6). They are characterized by their high content of acidic and basic amino acids ( $25 \%$ acidic and $25 \%$ basic residues) and their relatively low molecular weights (less than $30,000)(4,6,7,17)$. They can be isolated from chromatin with either $0.35 \mathrm{M}$-sodium chloride (6) or with $5 \%(w / v)$ perchloric acid $(15,16)$. The total HMG proteins are present in an amount equal to about $3 \%$ by weight of the histones in calf thymus (6). Four main components, calf HMG 1, 2, 14 and 17 have been isolated and characterized $(5,15,22,23)$.

The function of the HMG proteins is un- known, but a structural role in the chromatin has been suggested (6). Contradictory results have been obtained in studies designed to establish whether HMG proteins are preferentially located in actively transcribed regions of chromatin $(3,10,21)$.

The HMG proteins appear to be neither tissue nor species specific in mammals, and proteins similar to the HMG proteins have been isolated from duck erythrocytes (21), trout testis $(11,24)$, and Diptera $(1,2)$. Recent studies gave evidence for HMG-like proteins in plants and yeast $(18,19)$. In the present study we report further evidence that yeast contains HMG proteins. 


\section{MATERIALS AND METHODS}

\subsection{Isolation of yeast nuclei}

The diploid strain 11D of Saccharomyces cerevisiae (13) was grown in 4 liter YPD medium (1\% Bacto yeast extract, $2 \%$ Bacto peptone and $2 \%$ glucose) at $30^{\circ} \mathrm{C}$ on a gyratory shaker to the end of exponential growth phase $\left(3-6 \times 10^{7}\right.$ cells $\left.\cdot \mathrm{ml}^{-1}\right)$. The cells were harvested by centrifugation $(4,000 \times \mathrm{g}$ for $10 \mathrm{~min})$, washed twice in cold, deionized water, and then converted to spheroplasts by the following two-step procedure (14): The cell pellet (30-40 $\mathrm{g}$ wet weight) was resuspended in $5 \mathrm{vol}$. of $0.1 \mathrm{M}$ sodium thioglycollate (Sigma), $0.1 \mathrm{M}-\mathrm{Tris}-\mathrm{HCl}$ (pH 8.8), and then incubated for $30 \mathrm{~min}$ at $0-4^{\circ} \mathrm{C}$. The cells were washed three times in cold water and resuspended in $90 \mathrm{ml}$ of $1 \mathrm{M}$ sorbitol and $7 \mathrm{ml}$ of snail gut enzyme (suc d'helix pomatia, IBF, France) and incubated for $1-2$ hours at $30^{\circ} \mathrm{C}$ in a shaking water bath. When $90-95 \%$ of the cells had been converted into spheroplasts as judged by light microscopy, they were pelleted by centrifugation $(6,000 \times \mathrm{g}$ for $10 \mathrm{~min}$ ) and washed three times with $1 \mathrm{M}$ sorbitol containing $1 \mathrm{mM}$-phenylmethylsulfonyl fluoride (PMSF, Sigma) as protease inhibitor at $0-4^{\circ} \mathrm{C}$. All PMSF containing solutions were made up freshly prior to use in order to minimize hydrolyzation of the compound. PMSF was dissolved in absolute ethanol at a concentration of $80 \mathrm{~mm}$ and then the appropriate amount added to the required solution.

Nuclei were prepared from the spheroplasts by the following method $(12,25)$. All of the operations were performed at $0-4^{\circ} \mathrm{C}$. The spheroplasts were lysed by resuspending them in $120 \mathrm{ml}$ of $18 \%(\mathrm{w} / \mathrm{v})$ Ficoll 400 (Pharmacia, Sweden), 0.04 M-sodium hydrogen sulfite, 1 $\mathrm{mM}$-PMSF in $0.02 \mathrm{M}$-potassium phosphate buffer ( $\mathrm{pH}$ 6.5). The lysate was homogenized in a Potter-Elvehjem teflon homogenizer (4 strokes at 1,600 rpm), and unlysed cells or spheroplasts removed by centrifugation at $2,000 \times \mathrm{g}$ for 10 min. After discarding the pellet this centrifug- ation step was repeated twice. The supernatant was then spun at $30,000 \times \mathrm{g}$ for $25 \mathrm{~min}$ to pellet the nuclei. The crude nuclear pellet was resuspended in $120 \mathrm{ml}$ of $18 \%$ (w/v) Ficoll, $0.04 \mathrm{M}$ sodium hydrogen sulfite, $1 \mathrm{mM}$-PMSF in 0.02 M-phosphate buffer ( $\mathrm{pH} \mathrm{6.5)}$ by the use of a Potter-Elvehjem homogenizer. The suspension was divided into six parts, each of which was layered on top of $10-15 \mathrm{ml}$ of $30 \%$ (w/v) Ficoll, 1 mM-PMSF in 0.02 M-potassium phosphate buffer ( $\mathrm{pH}$ 6.5). Nuclei were then pelleted by centrifugation at $100,000 \times g_{\max }$ for 1 hour in a Beckman SW27 rotor. The six nuclear pellets with a packed volume of $0.5 \mathrm{ml}$ each were combined by resuspension in $3-4 \mathrm{ml}$ of $18 \%$ (w/v) Ficoll, $1 \mathrm{mM}-\mathrm{PMSF}, 0.02 \mathrm{M}$-phosphate buffer ( $\mathrm{pH} 6.5$ ), and the suspension stored frozen at $\div 70^{\circ} \mathrm{C}$ for less than 1 month.

\subsection{Extraction of HMG proteins and histones}

Six nuclear suspensions, prepared as described above, were thawed and combined, and nuclei were pelleted by centrifugation at $30,000 \times \mathrm{g}$ for $25 \mathrm{~min}$ at $0^{\circ} \mathrm{C}$. The nuclei were washed twice in 6 vol. of cold $0.14 \mathrm{M}$-sodium chloride, $0.005 \mathrm{M}$-Tris- $\mathrm{HCl}(\mathrm{pH} \mathrm{7.8)}$ with 0.5 $\mathrm{mM}$-PMSF by gentle resuspensions in a PotterElvehjem homogenizer and centrifugations at $8,000 \times \mathrm{g}$ for $10 \mathrm{~min} 0^{\circ} \mathrm{C}$. HMG proteins and possible histone Hl-like proteins were then extracted with perchloric acid and isolated by acetone precipitation as follows $(15,16)$ :

The nuclear pellet was extracted three times with 3 vol. of $5 \%(\mathrm{w} / \mathrm{v})$ PCA by resuspension and centrifugation at $8,000 \times \mathrm{g}$ for $10 \mathrm{~min}$. The combined extracts were clarified by centrifugation at $50,000 \times \mathrm{g}$ for $20 \mathrm{~min}$, and by filtration through a G20 sintered glass funnel. Then the solution was made $0.3 \mathrm{M}$ in hydrochloric acid by the addition of concentrated acid during stirring, and histone Hl-like material - if present precipitated by the addition of $3 \frac{1}{2} \mathrm{vol}$. of acetone, leaving the mixture at $\div 20^{\circ} \mathrm{C}$ overnight.

Abbreviations: $\mathrm{HMG}$ proteins $=$ high mobility group proteins, $\mathrm{PCA}=$ perchloric acid, $\mathrm{PMSF}=$ phenylmethylsulfonyl fluoride, SDS = sodium dodecyl sulfate. 
After the precipitate ( $100 \mathrm{mg}$ dry weight) containing very little protein had been removed by centrifugation at $5,000 \times \mathrm{g}$ for $15 \mathrm{~min}$, and the supernatant filtered through the G20 sintered glass to remove unpelleted precipitate, the HMG proteins were precipitated by adding further $2 \frac{1}{2}$ vol. of acetone (based on the original volume of the acidified PCA extract). Precipitation was allowed overnight at $\div 20^{\circ} \mathrm{C}$. The precipitate was collected by centrifugation at $5,000 \times \mathrm{g}$ for $15 \mathrm{~min}$, washed once in acetone- 0.1 $\mathrm{M}-\mathrm{HCl}(6: 1, \mathrm{v} / \mathrm{v})$ and three times in pure acetone and then dried in vacuo. The dried material was repurified by dissolving it in a small volume of $0.1 \mathrm{M}$-hydrochloric acid and fractional acetone precipitation as described above. The final HMG protein fraction was washed in acetone$\mathrm{HCl}$, then three times in acetone, and finally dried in vacuo. About eighty micrograms of presumed HMG proteins were obtained.

The nuclear pellet remaining after the PCA extractions served as a source of yeast histones. It was extracted three times with 3 vol. of 0.4 $\mathrm{M}$-hydrochloric acid by resuspension and centrifugation $(8,000 \times \mathrm{g}$ for $10 \mathrm{~min})$. The combined acid extracts were cleared by centrifugation $(50,000 \times \mathrm{g}$ for $20 \mathrm{~min})$ and by filtration through the G20 sintered glass. The yeast histones were precipitated by the addition of $8 \mathrm{vol}$. of acetone. The mixture was left overnight at $\div 20^{\circ} \mathrm{C}$. The precipitate was collected by centrifugation, washed in acetone- $\mathrm{HCl}$, acetone, and dried in vacuo. Eighteen milligrams of dried material were obtained in this fraction.

\subsection{Electron microscopy}

Nuclear pellets were fixed in $4 \%$ glutaraldehyde in 18\% (w/v) Ficoll, 0.02 M-potassium phosphate buffer (pH 6.5) overnight at $4^{\circ} \mathrm{C}$. The fixed material was washed twice with cold 0.05 M-potassium phosphate buffer ( $\mathrm{pH} \mathrm{6.8)}$ ), postfixed with $1 \%$ osmium tetraoxide in 0.05 M-potassium phosphate buffer ( $\mathrm{pH}$ 6.8), washed twice with buffer, dehydrated in a graded ethanol series, embedded in Spurr's low viscosity resin, and sectioned on a Reichert Om U3 ultramicrotome to give $80 \mathrm{~nm}$ thick sections. The sections were stained with uranyl acetate and lead citrate, and studied at primary magni- fications of $3,000-10,000$ in a Siemens Elmiscope 102.

\subsection{SDS-polyacrylamide gel electrophoresis}

The protein samples were analyzed by sodium dodecyl sulfate polyacrylamide gel electrophoresis $(9,20)$. The stacking gel was $4 \%$ in acrylamide and the separating gel $18 \%$ in acrylamide. The proteins were stained with Coomassie Brilliant Blue R-250 (Sigma).

\subsection{Amino acid analysis}

For amino acid analysis a sample of the yeast HMG protein fraction was hydrolyzed in 6 M-hydrochloric acid supplemented with $0.1 \%$ phenol for 24 hours at $110^{\circ} \mathrm{C}$ in vacuo. Amino acid analysis was done on a Durrum D-500 amino acid analyzer. No corrections were made for breakdown of threonine and serine, or for incomplete release of isoleucine and valine.

\section{RESULTS}

Several procedures were tested for their suitability for the isolation of yeast nuclei in good yields, morphological intactness, and reasonable purity. Though costly and time consuming, the isolation procedure based upon osmotic shock of yeast spheroplasts in the presence of Ficoll $(12,25)$ was chosen as the most satisfactory in these respects. The yield of nuclei was about $30-40 \%$. The integrity of the isolated nuclei, as judged by electron microscopy of fixed, imbedded and sectioned material, was retained (Figure 1). In some nuclei the spindle plaques and microtubuli could be observed (Figure 1, arrow). Phase contrast microscopy and electron microscopy give the impression that $25-35 \%$ of the observed particles are cell constituents other than nuclei. The major contaminants are unlysed spheroplasts, cell wall fragments and pieces of cytoplasm.

The SDS-polyacrylamide gel patterns of total nuclear proteins, the HMG protein fraction, and the yeast histones are shown in Figure 2. For comparison is also shown the pattern of calf thymus histones in track 5 . The latter is 


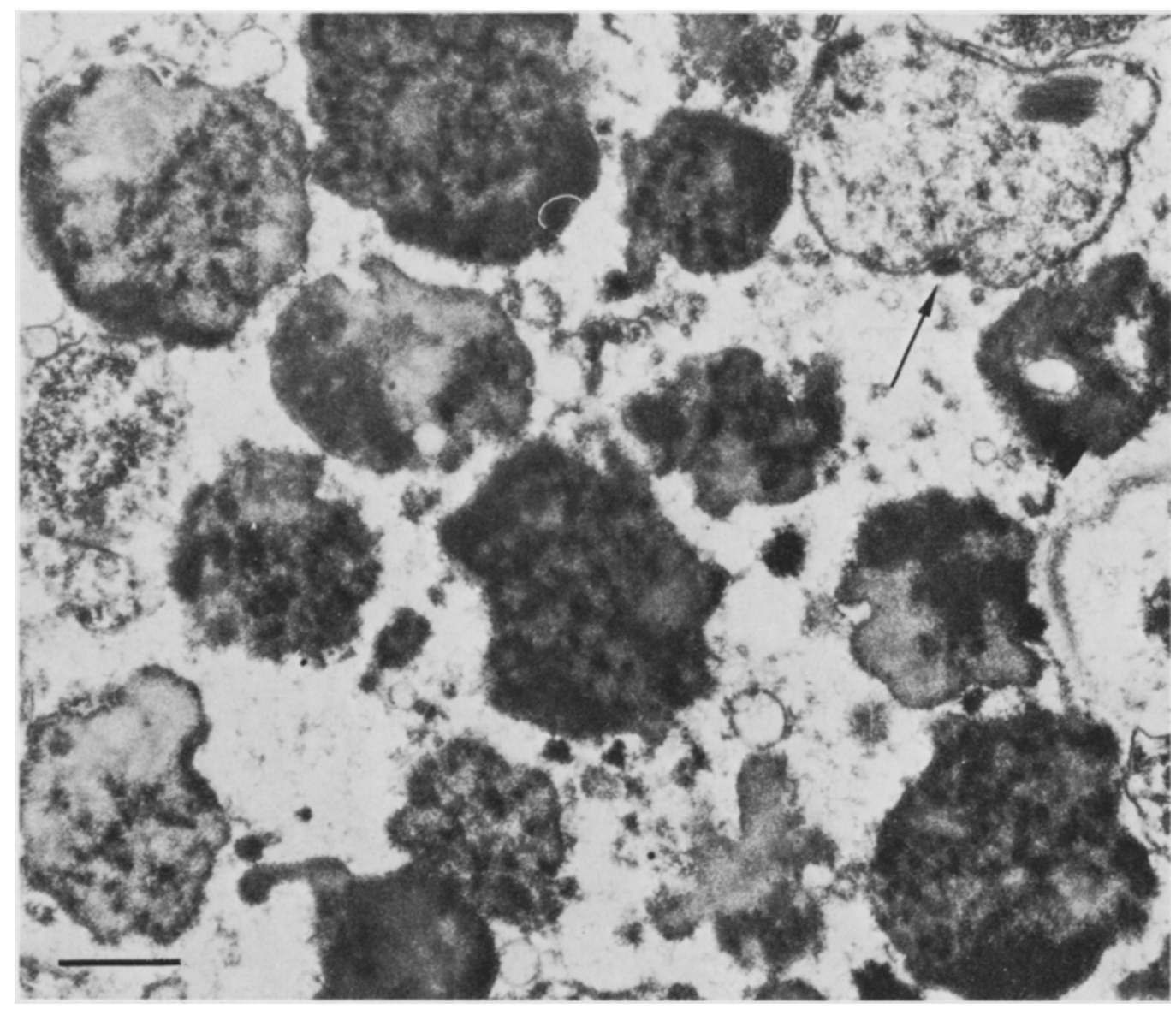

Figure 1. Electron micrograph of isolated yeast nuclei. The arrow indicates a spindle plaque with extending microtubules. The bar represents 1 micron. Magnification 14,400.

seen to consist of the four nucleosome core histones $\mathrm{H} 3, \mathrm{H} 2 \mathrm{~B}, \mathrm{H} 2 \mathrm{~A}$ and $\mathrm{H} 4$. In addition two weaker bands of the $\mathrm{Hl}$ histone are recognizable. The yeast histone fraction in track 1 is dominated by the four nucleosome core histone bands, which however, show slightly lower electrophoretic mobilities than those from calf thymus. There are about 12 additional minor protein bands in this fraction, which according to the procedure used is not expected to contain $\mathrm{Hl}$ histone. Among the great number of bands observable with the unfractionated nuclear proteins of yeast (track 4) the four nucleosome core histones constitute the major proteins in the low molecular weight region.

The gel pattern of the HMG protein sample from yeast (tracks 2 and 3) shows 9 protein bands labelled a to $i$. Band $b$ is present in so low amounts that it does not show up in the photographic reproduction and also bands $a$ and $h$ are barely visible. The four major protein bands (labelled d, e, g and i) have mobilities close to the histones, indicating low molecular weights as expected for HMG proteins. An alternative method to extract HMG proteins from chromatin of higher eukaryotes employs $0.35 \mathrm{M}$ - 

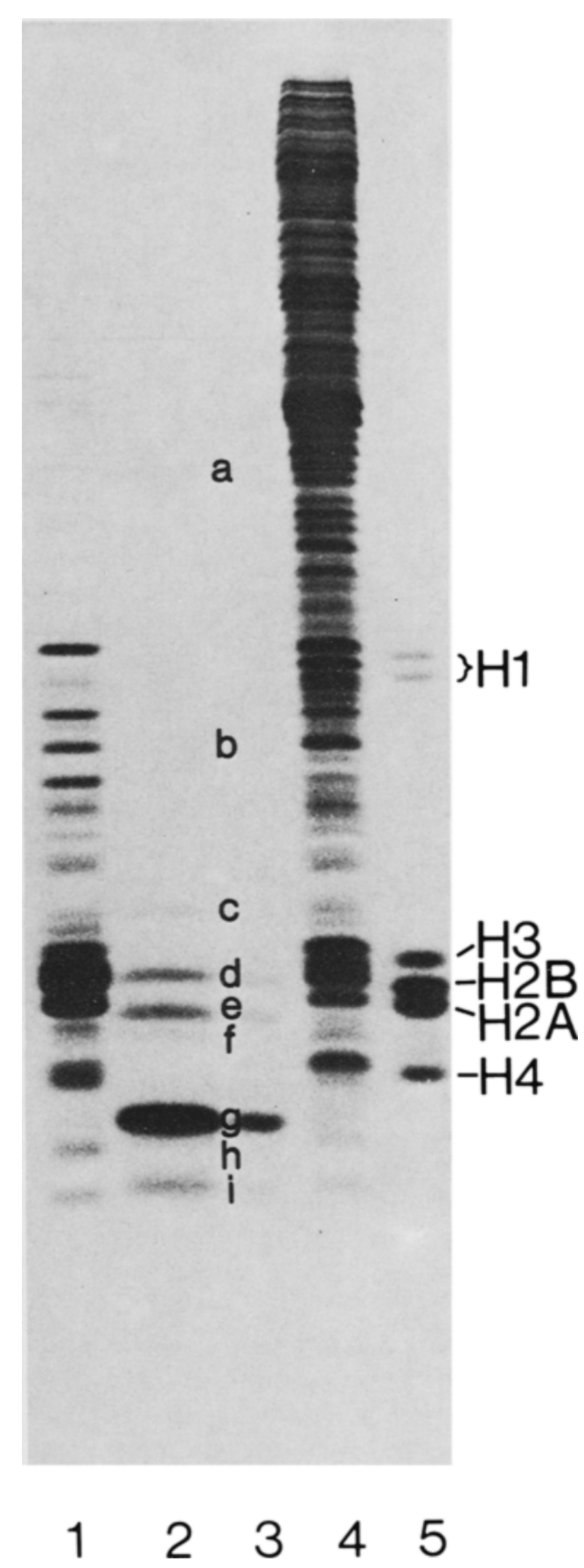

Figure 2. SDS-polyacrylamide gel electrophoresis patterns of nuclear proteins in yeast. Sample 1: Yeast histone fraction, isolated from yeast nuclei after perchloric acid extraction, $13 \mu \mathrm{g}$ of protein. Sample 2: Yeast HMG proteins isolated from yeast nuclei by PCA extraction and fractional acetone precipitation, $20 \mu \mathrm{g}$ of protein. Sample 3: Yeast HMG proteins, same as sample 2, $4 \mu \mathrm{g}$ of protein. Sample 4: Total yeast nuclear proteins. Nuclei were washed twice in $0.14 \mathrm{M}-\mathrm{NaCl}, 0.05 \mathrm{M}-\mathrm{Tris}-\mathrm{HCl}$ (pH 7.8) with 0.5 mM-PMSF, and a small sample solubilized in SDS sample buffer. Sample 5: Calf thymus histones (Sigma), $8 \mu \mathrm{g}$ of protein.

sodium chloride followed by fractional trichloroacetic acid precipitation (6). When yeast nuclei are extracted with $0.35 \mathrm{M}-\mathrm{NaCl}$, and the proteins which remain soluble in the extract after precipitation with $2 \%$ trichloroacetic acid are analyzed by SDS-polyacrylamide gel electrophoresis, a pattern with 9 bands is obtained which is very similar to that of the perchloric acid extract given in Figure 2 tracks 2 and 3. In this Figure the bands a to $i$ have the following mobilities relative to calf thymus histone $\mathrm{H} 4$ : $\mathrm{a}-0.43$, b-0.70, c- 0.85 , d- 0.91 , e- $0.95, \mathrm{f}-0.96$, g-1.04, h-1.07, i-1.11. The mobilities of the bands observed with the $\mathrm{NaCl}$ extract were: $\mathrm{a}-0.44$, b-0.60, c-0.84, d-0.90, e-0.94, f-0.96, $\mathrm{g}-1.05, \mathrm{~h}-1.07, \mathrm{i}-1.10$. The only significant difference is revealed by the two bands designated as b.

In another experiment, the SDS gel patterns of yeast HMG proteins were compared to a sample of calf thymus HMG proteins kindly provided by G. H. GooDwIN. The major yeast HMG proteins had higher mobilities (lower molecular weights) than calf HMG proteins. None of the yeast HMG proteins seemed to correspond to the major calf HMG proteins 1,2 and 14 , but had mobilities in the region of calf HMG 17 and some minor, as yet uncharacterized, calf HMG proteins (G. H. GooDwIN, personal communication).

The HMG protein fraction was subjected to amino acid analysis (Table I). For comparison is shown the amino acid composition of calf thymus HMG proteins (6). The yeast HMG protein fraction contained $9.0 \%$ aspartic and 
Table I

Amino acid compositions (moles \% of yeast and calf thymus HMG proteins). The amino acid composition of calf HMG proteins is taken from Goodwin et al. (6).

\begin{tabular}{ccc}
\hline $\begin{array}{c}\text { Amino acid } \\
\text { residue }\end{array}$ & $\begin{array}{c}\text { Yeast HMG } \\
\text { proteins }\end{array}$ & $\begin{array}{c}\text { Calf thymus } \\
\text { HMG proteins }\end{array}$ \\
\hline Asx & 9.0 & 7.7 \\
Thr & 5.3 & 4.1 \\
Ser & 4.2 & 7.5 \\
Glx & 10.5 & 11.7 \\
Pro & 7.5 & 6.8 \\
Gly & 7.5 & 7.1 \\
Ala & 9.0 & 14.2 \\
Val & 5.5 & 4.4 \\
Met & 1.3 & 0.0 \\
Cys & - & 0.6 \\
Ile & 3.1 & 1.9 \\
Leu & 7.8 & 5.1 \\
Tyr & 3.0 & 1.6 \\
Phe & 1.9 & 2.7 \\
His & 1.5 & 1.1 \\
Lys & 15.4 & 18.5 \\
Arg & 7.6 & 4.1 \\
\hline
\end{tabular}

$10.5 \%$ glutamic acid residues, giving a total of $19.5 \%$ acidic amino acid residues, and $15.4 \%$ of lysine and $7.6 \%$ arginine residues, a total of $23.0 \%$ of basic amino acids. The sums of the acidic and basic amino acid residues are close to those of calf thymus HMG proteins.

\section{DISCUSSION}

Since no functional criteria are available to define an HMG protein, we and other workers have used the characteristic amino acid composition, the low molecular weight, and the extraction and solubility properties to judge whether or not a protein is an HMG protein. In order to further ensure that the class of proteins which were isolated as HMG proteins from yeast are indeed HMG proteins, each protein band should be isolated and characterized. This has not been attempted in this study, due to low yields. It is possible that some of the nine polypeptide bands are cytoplasmic contaminants or degradative products of histones or other chromosomal proteins.
Our evidence for the existence of HMG proteins in yeast similar to those found in higher eukaryotes is the following:

(1) A class of proteins can be extracted from isolated yeast nuclei by perchloric acid and purified by fractional acetone precipitation, as described for higher eukaryotes $(15,16)$, and by the alternative method employing $0.35 \mathrm{M}$ sodium chloride followed by fractional trichloroacetic acid precipitation (6).

(2) SDS-polyacrylamide gel electrophoresis suggests they are proteins of low molecular weights, comparable in size to histones and small calf thymus HMG proteins.

(3) The amino acid composition is similar to that of calf thymus HMG proteins, and shows the high contents of acidic and basic amino acids characteristic of $\mathrm{HMG}$ proteins. From the yields of HMG proteins and histones we have estimated a weight ratio of about 1:200 of HMG proteins to histones. This is lower than the value of 1:30 reported for calf thymus (6). It is possible that yeast contains less HMG proteins in relation to histones than calf. However, it is also possible that HMG proteins have been lost during isolation.

HMG proteins in yeast have recently been reported in two other studies $(18,19)$. In both studies, a single major protein in the isolated yeast histone fraction was found to have HMGlike amino acid composition. The close similarities in both reports between the amino acid compositions and the positions of the bands in polyacrylamide gels (migrating slightly slower than the histones) suggest, that it may well be the same protein. SOMMER (18) suggested that the protein might be an early form of histone $\mathrm{Hl}$, so far undemonstrated in yeast. He noted that the protein was not soluble in 5\% perchloric acid. In agreement with this result, we did not find a major HMG protein in our extracts moving to that position in polyacrylamide gels. It therefore appears that the class of $\mathrm{HMG}$ proteins we have studied does not include the earlier reported yeast HMG-like protein(s), but another class of HMG proteins in yeast, which in addition to amino acid composition and electrophoretic mobility, also show the selective extractability, characteristic of HMG proteins in mammalian tissues. 


\section{ACKNOWLEDGEMENTS}

The authors wish to thank B. CORNELIUSSEN and C. POULSEN for help in the amino acid analysis, M. C. KIELland-BRANDT, T. NILSSONTillgren, B. Christensen, S. HOLMBERG and B. WILKEN for many discussions, and D. VON WETTSTEIN for critically reading the manuscript.

The work was in part supported by a Fulbright-Hays Research grant to W. F. SHERIDAN and grant GM 22051 from the U.S. Public Health Service, National Institutes of Health to D. von WeTtSTEIN.

\section{REFERENCES}

1. Alfageme, C. R., G. T. Rudkin \& L. H. Cohen: Locations of chromosomal proteins in polytene chromosomes. Proc. Nat. Acad. Sci. USA 73, 2038-2042 (1976)

2. Franco, L,, F. Montero \& J. J. RodriguezMolina: Purification of the histone Hl from the fruit fly Ceratitis capitata. Isolation of a high mobility group (HMG) non-histone protein and - aggregation of $\mathrm{H} 1$ through a disulphide bridge. FEBS Letters 78, 317-320 (1977)

3. Goodwin, G. H. \& E. W. Johns: Are the high mobility group non-histone chromosomal proteins associated with "active" chromatin? Biochim. Biophys. Acta 519, 279-284 (1978)

4. Goodwin, G. H. \& E. W. Johns: Isolation and characterisation of two calf-thymus chromatin non-histone proteins with high contents of acidic and basic amino acids. Eur. J. Biochem. 40, 215-219 (1973)

5. Goodwin, G. H., A. Rabbani, R. H. Nicolas \& E. W. JoHns: The isolation of the high mobility group non-histone chromosomal protein HMG 14. FEBS letters 80, 413-416 (1977)

6. Goodwin, G. H., C. Sanders \& E. W. Johns: A new group of chromatin-associated proteins with a high content of acidic and basic amino acids. Eur. J. Biochem. 38, 14-19 (1973)

7. Goodwin, G. H., K. V. Shooter \& E. W. Johns: Interaction of a non-histone chromatin protein (high-mobility group protein 2) with DNA. Eur. J. Biochem. 54, 427-433 (1975)

8. Goodwin, G. H., L. Woodhead \& E. W. Johns: The presence of high mobility group non-histone chromatin proteins in isolated nucleosomes. FEBS Letters 73, 85-88(1977)
9. LAEMmLI, U. K.: Cleavage of structural proteins during the assembly of the head of bacteriophage T4. Nature 227, 680-685 (1970)

10. Levy, W. B., N. C. W. Wong \& G. H. Dixon: Selective association of the trout-specific $\mathrm{H} 6$ protein with chromatin regions susceptible to Dnase I and DNase II: Possible location of HMG-T in the spacer region between core nucleosomes. Proc. Nat. Acad. Sci. USA 74, 2810-2814 (1977)

11. Marushige, K. \& G. H. Dixon: Transformation of trout testis chromatin. J. Biol. Chem. 246, 5799-5805 (1971)

12. MAY, R.: Isolationsbedingungen für Zellkerne aus Hefeprotoplasten. Z. Allg. Microbiol. 11, 131-142 (1971)

13. Petersen, J. G. L., L. W. Olson \& D. Zckler: Synchronous sporulation of Saccharomyces cerevisiae at high cell concentrations. Carlsberg Res. Commun. 43, 241-253 (1978)

14. Piñon, R.: Effects of ammonium ions on sporulation of Saccharomyces cerevisiae. Exptl. Cell Res. 105, 367-378 (1977)

15. SANDERs, C.: A method for the fractionation of the high-mobility-group non-histone chromosomal proteins. Biochem. Biophys. Res. Comm. 78, 1034-1042 (1977)

16. SANDERS, C. \& E. W. Johns: A method for the large-scale preparation of two chromatin proteins. Biochem. Soc. Trans. 2, 547-550 (1974)

17. Shooter, K. V., G. H. Goodwin \& E. W. Johns: Interactions of a purified non-histone chromosomal protein with DNA and histone. Eur. J. Biochem. 47, 263-270 (1974)

18. SOMmer, A.: Yeast chromatin: Search for histone H1. Molec. gen. Genet. 161, 323-331 (1978)

19. Spiker, S., J. K. W. Mardian \& I. Isenberg: Chromosomal HMG proteins occur in three eukaryotic kingdoms. Biochem. Biophys. Res. Comm. 82, 129-135 (1978)

20. Thomas, J. O.\& R. D. Kornberg: An octamer of histones in chromatin and free in solution. Proc. Nat. Acad. Sci. USA 72, 2626-2630(1975)

21. Vidali, G., L. C. Boffa \& V. G. Allfrey: Selective release of chromosomal proteins during limited DNase 1 digestion of avian erythrocyte chromatin. Cell 12, 409-415 (1977)

22. Walker, J. M., G. H. Goodwin, E. W. Johns, P. Wietzes \& W. GaAstra: A comparison of the amino-terminal sequences of two calf-thymus chromatin non-histone proteins. Int. J. Peptide Protein Res. 9, 220-223 (1977)

23. Walker, J. M., J. R. B. Hastings \& E. W. Johns: The primary structure of a non-histone chromosomal protein. Eur. J. Biochem. 76, 461-468 (1977) 
24. Watson, D. C., E. H. Peters \& G. H. Dixon: The purification, characterization and partial sequence determination of a trout testis nonhistone protein, HMG-T. Eur. J. Biochem. 74, 53-60(1977)
25. Wintersberger, U., P. Smith \& K. Letnansky: Yeast chromatin. Preparation from isolated nuclei, histone composition and transcription capacity. Eur. J. Biochem. 33, 123-130 (1973) 